\title{
Revisiting the bi-directional causality between debt and growth: Evidence from linear and nonlinear tests
}

\author{
De Vita, G, Trachanas, E \& Luo, Y
}

Author post-print (accepted) deposited by Coventry University's Repository

Original citation \& hyperlink:

De Vita, G, Trachanas, E \& Luo, Y 2018, 'Revisiting the bi-directional causality between debt and growth: Evidence from linear and nonlinear tests' Journal of International Money and Finance, vol 83, pp. 55-74

https://dx.doi.org/10.1016/i.jimonfin.2018.02.004

DOI $\quad$ 10.1016/j.jimonfin.2018.02.004

ISSN 0261-5606

ESSN $\quad 1873-0639$

\section{Publisher: Elsevier}

NOTICE: this is the author's version of a work that was accepted for publication in Journal of International Money and Finance. Changes resulting from the publishing process, such as peer review, editing, corrections, structural formatting, and other quality control mechanisms may not be reflected in this document. Changes may have been made to this work since it was submitted for publication. A definitive version was subsequently published in Journal of International Money and Finance, [83, (2018)] DOI: 10.1016/j.jimonfin.2018.02.004

(C) 2018, Elsevier. Licensed under the Creative Commons AttributionNonCommercial-NoDerivatives 4.0 International http://creativecommons.org/licenses/by-nc-nd/4.0/

Copyright $(\subseteq$ and Moral Rights are retained by the author(s) and/ or other copyright owners. A copy can be downloaded for personal non-commercial research or study, without prior permission or charge. This item cannot be reproduced or quoted extensively from without first obtaining permission in writing from the copyright holder(s). The content must not be changed in any way or sold commercially in any format or medium without the formal permission of the copyright holders.

This document is the author's post-print version, incorporating any revisions agreed during the peer-review process. Some differences between the published version and this version may remain and you are advised to consult the published version if you wish to cite from it. 


\title{
The Impact of FDI on Nigeria's Exports: A Sectoral Analysis
}

\author{
Obiora G. Okechukwu ${ }^{1}$, Glauco De Vita ${ }^{2, *}$, Yun Luo ${ }^{3}$ \\ ${ }^{1}$ Centre for Business in Society, Coventry University, Priory Street, Coventry CV1 5FB, UK. \\ Tel.: +44(0)2476887688. E-mail: okechuko@uni.coventry.ac.uk \\ ${ }^{2}$ Centre for Business in Society, Coventry University, Priory Street, Coventry CV1 5FB, UK. \\ Tel.: +44(0)2476887688. E-mail: glauco.devita@coventry.ac.uk.*Corresponding author. \\ ${ }^{3}$ Centre for Business in Society, Coventry University, Priory Street, Coventry CV1 5FB, UK. \\ Tel.: +44(0)2476887688. E-mail: yun.luo@coventry.ac.uk
}

Accepted by Journal of Economic Studies on $9^{\text {th }}$ of February 2018

\begin{abstract}
Purpose - The purpose of this paper is to examine the FDI-exports relationship in Nigeria using disaggregated FDI and export data.

Design/methodology/approach - This paper applies the ARDL cointegration approach in examining the long-run relationship between FDI and exports.

Findings - Our results suggest that aggregate FDI has a positive and statistically significant long-run impact on total exports. Once exports are disaggregated into oil and non-oil exports, the positive, cointegrating relationship holds only for oil exports. When disaggregated by sector, primary sector and manufacturing sector FDI have a positive and significant long-run relationship with both total exports and oil exports but service sector FDI does not appear to have any significant influence on Nigerian exports.

Originality/value - This is the first paper that employs both sectoral FDI and disaggregated export data to examine the FDI-exports nexus in Nigeria.
\end{abstract}

Keyword FDI, Export, Nigeria

Paper type Research paper 


\section{Introduction}

Although much empirical work has focused on understanding how foreign direct investment (FDI) and the underlying mediating factors affect the growth and productivity of a host country, the relationship between FDI and a host country's export performance has received considerably less attention. More so, many of the studies on the FDI-exports nexus have focused on developed and transition economies, with little attention being paid to developing economies, especially Sub-Saharan African (SSA) countries.

One of the earliest theoretical frameworks on the relation between FDI and international trade was advanced by Mundell (1957) in his seminal work based on the neoclassical Hecksher-Ohlin's model based on two countries, two commodities and two factors. In his analysis, Mundell relaxes the assumption of immobility of factors of production and argues that factor movement can substitute for trade. He hypothesises that trade barriers will encourage cross-border factor movement, and that trade, on the other hand, would boom in the presence of restrictions on factor movement. This implies that FDI and exports can substitute each other depending on the degree of openness of the host and home country. Later theories such as the internalisation theory (Buckley and Casson, 1976) further emphasise the substitutive relationship between FDI and trade. In deciding to enter a foreign market, firms are likely to undertake FDI rather than exports if the benefits that accrue to them by internalising their ownership advantages exceed the cost of market imperfections.

Although many of the theoretical treatments of FDI and trade have often included outward FDI and imports, the precise relationship between inward FDI and exports remains ambiguous and may depend on the type of FDI. According to Vuksic (2005), FDI that is predicated on taking advantage of the availability of natural resources or low-cost labour is more likely to directly promote exports. Vertically integrated FDI that is resource seeking 
would be expected to increase the volume of the host country's exports, with the subsidiaries of the MNEs focused on exporting raw materials or intermediate products to their parent firm or other subsidiaries. The effect of horizontal FDI, on the other hand, on the export performance of a host country is ambiguous. Jensen (2002) observed that this type of FDI, especially when it is 'market-seeking', may not have any direct impacts on exports as it is targeted primarily at the host country market. However, Franco (2013) argues that marketseeking horizontal FDI does indeed have the potential to promote host country exports through export spillover to domestic firms. Her results show that while market-seeking FDI may not contribute directly to exports, by strengthening the links with domestic firms, it may indirectly boost the exporting capacity of domestic firms. In other words, market-seeking horizontal FDI also has a potentially positive effect on exports when it boosts local entrepreneurship through competition with domestic firms as well as through links with firms in their downstream and upstream of the MNE's supply chain.

The empirical literature on the effect of FDI on host country exports can be broadly divided into two strands: (i) studies that focus on the direct contribution of FDI to exports; and (ii) studies that examine the indirect (spillover) effect of FDI on domestic firms' exports. In the present study, due to a lack of firm-level data for Nigeria, we focus on the direct effect of FDI. The empirical evidence from this stream of literature is mixed. Some studies found evidence of a positive relationship (e.g., Leichenko et al., 1997; Xuan and Xing, 2008), while others show that the impact of FDI on host country exports may not always be positive (e.g., Lall and Mohammed, 1983; Sharma, 2003). Furthermore, most of these studies make use of aggregate FDI and aggregate export data at either cross-national, national or regional level. As noted by Alfaro (2003), aggregate FDI does not give the full picture of the impact of FDI. Data aggregation may also be the reason for the mixed findings of previous work. 
The present study adds to this literature by employing disaggregated sectoral FDI and oil/non-oil export data to examine the FDI-exports relationship in Nigeria. Nigeria makes for an interesting case to study the FDI-export nexus. For over a decade now, Nigeria has consistently remained one of the top destinations of FDI in Africa. Figure 1 shows the top 10 destinations of FDI in Africa (average from 1980 to 2015) and Nigeria is the second-ranked African country in terms of inward FDI. Moving away from a largely agrarian economy to an oil-dominated economy, Nigeria's FDI has also historically tilted towards the oil sector. As seen in Figure 2, for most of the 1990s, the primary sector (consisting largely of oil and allied sector) was the major recipient of FDI. However, this trend has been reversing since the early 2000s, as Nigeria has recorded massive FDI inflows into other sectors, particularly the manufacturing sector - also thanks to the extensive privatisation of public enterprises carried out by the new civilian government (UNCTAD, 2009).

[Insert Figure 1 and Figure 2 here]

Despite being one of the largest recipients of FDI in Africa, only very few empirical studies have examined the FDI-exports relationship in Nigeria. The notable exceptions are Mohammed and Ekundayo (2014), Aigheyisi (2016), and Enimola (2011). Unlike Enimola (2011), who investigated the FDI-export nexus at aggregate level, Mohammed and Ekundayo (2014) and Aigheyisi (2016) disaggregated export categories into oil and non-oil, taking into account the predominance of the oil sector in Nigeria. However, none of these studies attempted to examine the impact of sectoral FDI across different export categories.

We disaggregate FDI into primary sector, manufacturing sector FDI and service sector FDI, and investigate their impact across different export categories by distinguishing between oil and non-oil exports. By disaggregating FDI by sector, we are also able to infer how the 'FDI motivation' affects its relation with exports. Primary sector FDI, especially in 
developing countries, is mostly resource-seeking and vertically integrated (Alfaro, 2003), and hence is more likely to promote resource exports (in this study, oil) than non-resource (nonoil) exports. Service sector FDI and manufacturing FDI, on the other hand, may either be market-seeking or efficiency-seeking, hence they may have a differentiated impact on resource and non-resource product exports.

\section{A synthesis of related empirical literature}

The empirical evidence is mixed. Studies by Leichenko et al. (1997), Sun (2001), Zhang (2002; 2005), Liu and Shu (2003), Wang et al. (2007) and Xuan and Xing (2008) find evidence of a positive relationship between FDI and exports at the national and regional level. However, there is also conflicting evidence for some countries. For example, Sharma (2003) investigated the contribution of FDI to India's exports over the period 1970-1998 and found that FDI did not have any significant impact. This result supports the earlier finding by Lall and Mohammed (1983) for India. To explain the absence or, at best, marginal contribution of FDI to exports in their findings, Lall and Mohammed (1983) and Sharma (2003) point out that the inward-oriented policy of the Indian government during the sample period, effectively discouraged exports. Likewise, in a study of 12 Central and Eastern European countries, Kutan and Vuksic (2007) found that the FDI-specific effect on exports was positive and statistically significant only for the eight countries grouped under the New European Union (NEU) members, and statistically insignificant for the other four Southeast European countries. They argue that the difference in FDI impact is likely to result from the fact that the level of FDI inflows and initial level of productivity of domestic firms in the NEU countries, are higher than in the Southeast European countries. 
Another possible reason for the divergence in results of FDI-exports studies is that the type and level of aggregation of the data matters. Most existing studies make use of aggregate FDI and aggregate export data. However, it is likely that the use of aggregate FDI and export data masks sectoral differences in the impact of FDI on different export categories (Alfaro, 2003). Her results show that while total FDI may have a positive effect on the host country's growth, when disaggregated by sector, primary sector, manufacturing sector, and service sector FDI have different effects on growth. Similarly, while FDI inflows may promote exports at aggregate national or regional level, not all product exports may be affected in the same way. Moreover, although not related to the FDI-exports literature, Li et al. (2017) attribute the use of sectoral FDI to the underlying sector-specific characteristics and the fixed costs associated with the nature of such inward investments, which are generally higher for primary sector FDI. In turn, this would imply that oil exports which typically entail use of technological advantages embedded in 'resource seeking' inward FDI which is expected to incur high fixed costs, need to generate more profits through export revenues. Manufacturing and services FDI, on the other hand, incur lower fixed costs, are relatively more mobile, and hence less inclined to seek extra profits through exports.

In a study on the effect of FDI on the exports of 10 Economic Community of West African States (ECOWAS), Onyekwena et al. (2015) disaggregate exports into three categories: primary, intermediate, and final commodities. Their results show that FDI has a positive relationship with primary goods exports, a negative relationship with intermediate goods exports, and an insignificant impact on final goods exports. Using a similar approach, Gu et al. (2008) and Liu and Shu (2003) examine the impact of FDI on different categories of exports in China. Liu and Shu (2003) found that the effect of FDI on total exports is positive, and this result is robust when exports are disaggregated into high and low technology sectors' exports. Gu et al. (2008) obtained similar results after disaggregating industrial exports into 
14 sectors. They find that the effect of FDI is positive and significant in 13 out of the 14 sectors considered. These findings are consistent with those of Leichenko and Erickson (1997), who found that the impact of FDI on exports is positive in all but two of the manufacturing industries considered. Taken together, what these studies suggest is that the impact of FDI (total or disaggregated) may not be the same across all export categories.

\section{Theoretical and empirical framework}

\subsection{Hypotheses}

We state two hypotheses to frame the empirical analysis.

Hypothesis 1: Aggregate inward FDI has a positive effect on the volume of exports in Nigeria.

As we have argued in the literature review, MNEs' affiliates are usually more productive and more likely to export as they possess specific ownership advantages, which may include having more knowledge about the workings of the international market. Moreover, MNEs are typically large firms, with superior technologies and financial means, hence better able than most domestic firms to afford the high fixed costs associated with exporting (Gorg and Greenaway, 2001). Hence, it is reasonable to expect that aggregate inward FDI may affect positively the volume of total exports in the host country.

While we expect that FDI has a positive effect on the total volume of exports, there is evidence in the literature that suggests that the impact of aggregate FDI on exports may vary across different export categories. For instance, Onyekwena et al. (2015) found that FDI does not have the same impact on primary products, intermediate and finished product exports in West Africa. This highlights the need to disaggregate exports into different categories in 
order to assess the differential effect of aggregate FDI across the categories. Following related literature pertaining to the Nigerian experience, we disaggregate exports into oil and non-oil exports. The distinction is motivated by the fact that oil plays a significant role in Nigeria's economy. A large proportion of Nigeria's inward FDI goes to the oil sector and the sector's exports make up a very high percentage of total exports (Olayiwola and Okodua, 2013). Figure 3 shows the summary of exports in Nigeria and the dominance of oil exports in total exports. Consequently, this hypothesis aims to examine the effect of aggregate inward FDI on total exports, as well as oil and non-oil exports.

[Insert Figure 3 here]

Hypothesis 2: Sectoral FDI has a varied effect on export volume in Nigeria.

The aim of Hypothesis 2 is to investigate the relationship between sectoral FDI - primary sector FDI, manufacturing sector FDI and service sector FDI - and Nigeria's exports. As noted in our literature review, increasing evidence suggests that the type and extent of the impact that FDI has on a host country will vary when total FDI is disaggregated by sectors (e.g., Alfaro, 2003; Li et al., 2017). The use of aggregate FDI data may not reveal the whole picture, as it may obscure the fact that the impact of FDI is unlikely to be equal for all recipient sectors.

\subsection{Model specification}

In the previous section, we stated the two hypotheses to be subjected to empirical scrutiny. To test the first hypothesis, we specify the following three models:

$\operatorname{LnEXP} P_{t}=\beta_{0}+\beta_{1} \ln F D I_{t}+\beta_{2} \ln R E E R_{t}+\beta_{3} \ln G D P_{t}+\mu_{t}$ 
$\operatorname{LnOEXPt}=\alpha_{0}+\alpha_{1} \ln F D I_{t}+\alpha_{2} \operatorname{lnREER_{t}}+\alpha_{3} \ln G D P_{t}+\varepsilon_{t}$

$L n N E X P t=\delta_{0}+\delta_{1} \ln F D I_{t}+\delta_{2} \operatorname{lnREER_{t}}+\delta_{3} \ln G D P_{t}+\eta_{t}$

In equations 1-3 above, the explanatory variables are the same while the dependent variable is different in each equation. $L n E X P$ is the total amount of annual exports in log form, LnOEXP and LnNEXP stand for oil and non-oil exports in log form, respectively. LnFDI, LnREER and $L n G D P$ represent aggregate FDI, the real effective exchange rate and gross domestic product, respectively, in log form.

Next, we propose three further models to test the second hypothesis. We disaggregate FDI into three broad sectors, primary sector FDI, manufacturing sector FDI, and service sector FDI, and estimate their long-run relationship with the different export categories.

$L n T E X P t=n_{0}+n_{1} \ln P F D I_{t}+n_{2} \operatorname{lnMFDI}_{t}+n_{3} \operatorname{lnSFDI_{t}}+n_{4} \ln R E E R_{t}+n_{5} \ln G D P_{t}+v_{t}$

$L n O E X P t=h_{0}+h_{1} \ln \mathrm{PFDI}_{t}+h_{2} \operatorname{lnMFDI}_{t}+h_{3} \operatorname{lnSFDI_{t}}+h_{4} \ln R E E R_{t}+h_{5} \ln G D P_{t}+\varphi_{t}$

$\operatorname{LnNEXPt}=m_{0}+m_{1} \ln P F D I_{t}+m_{2} \ln M F D I_{t}+m_{3} \operatorname{lnSFDI_{t}}+m_{4} \ln R E E R_{t}+m_{5} \ln G D P_{t}+\chi_{t}$

The dependent and explanatory variables in equations 4-6 are identical to those in equations 1-3. The only difference is that, in equations 4-6, FDI is disaggregated into primary sector FDI $(P F D I)$, manufacturing sector FDI $(M F D I)$, and service sector FDI (SFDI).

\subsection{Data and method}

Annual time series data were obtained from different sources. Data on FDI, REER and GDP were obtained from the World Development Indicators (WDI) database of the World Bank, while data on sector FDI and exports were collected from the Central Bank of Nigeria (CBN) 
statistical bulletins. For the first hypothesis involving total FDI, the sample period is from 1980 to 2015 . For the second hypothesis covering disaggregated FDI, the sample period is limited to 1981-2009. Both sample periods are dictated by the availability of data.

To avoid the risk of running regressions with nonstationary time series, we follow the literature (e.g., Bahmani-Oskooee and Hajilee, 2013) by testing for the stationarity of the variables. To this end, we apply the Ng and Perron (2001) and the augmented Dicky-Fuller (ADF) unit root tests.

Next, we employ the Autoregressive Distributed Lag (ARDL) cointegration approach (Pesaran and Shin, 1999; Pesaran et al., 2001) to test for, and estimate, both the long- and short-run relationships between the variables. Unlike other cointegration methods, the ARDL approach is the most suitable for testing the long-run relationship among the variables when it is not known with certainty whether the regressors are purely $\mathrm{I}(0)$, purely $\mathrm{I}(\mathrm{I})$ or mutually cointegrated, as long as none of the regressors is integrated of order two (De Vita and Abbott, 2002). Fousekis et al. (2016) highlight several advantages of the ARDL approach to cointegration testing. It performs better in small samples compared to alternative multivariate cointegration procedures and is more efficient than the standard Engle and Granger two step approach. To illustrate, the ARDL $\left(\underline{p, q)}\right.$ cointegration model with two time series $y_{t}$ and $x_{t}$ $(t=1,2, \ldots, \mathrm{T})$ has the following form:

$$
\Delta y=\alpha_{0}+\rho y_{t-1}+\theta x_{t-1}+\gamma z_{t}+\sum_{j=1}^{p-1} a_{j} \Delta y_{t-j}+\sum_{j=0}^{q-1} \pi_{j} \Delta x_{t-j}+e_{t}
$$

where $z_{t}$ is a vector of deterministic regressors, and $e_{t}$ is a random disturbance term (an iid stochastic process).

Pesaran et al. (2001) show that the null of 'no cointegration', i.e., $H_{0}: \rho=\theta=0$, against the alternative hypothesis $H_{1}: \rho \neq 0$ or $\theta \neq 0$, can be tested by employing a modified 
$F$-test. Alternatively, the $t$-BDM test proposed by Banerjee et al. (1998), which tests the null of no cointegration $\rho=0$ against the alternative $\rho<0$, can be employed. The test procedure involves an upper bound and a lower bound. If the estimated value of the modified F or tBDM statistic exceeds the upper critical bound then the null is rejected (i.e., $y_{t}$ and $x_{t}$ are cointegrated), if it lies below the lower critical bound the null cannot be rejected (i.e., $y_{t}$ and $x_{t}$ are not cointegrated), and if it lies between the critical bounds the test is inconclusive.

In terms of model selection, we apply the Akaike information criterion (AIC) rather than the Schwarz information criterion (SIC) since although by leading to lower order models for forecasting the latter has been found to be preferable judged on its ability to predict future values of the time series (see, e.g., Koehler and Murphree, 1988), if the chief objective is to explain the nature of the system generating the series - as in our case - the AIC is preferable given that SIC is stricter than AIC in penalising loss of degrees of freedom.

\section{Results}

\subsection{Unit roots and ARDL cointegration}

In Table I, the unit root test results for the variables in the first three models (equations 1-3) are presented while Table II summarises the unit root test results for the variables in equations 4 to 6 . Despite a few discrepancies between the 'constant only' and 'constant and trend' specifications, the Ng-Perron and ADF unit root test results show that all the variables are $\mathrm{I}(0)$ or $\mathrm{I}(1)$ but not $\mathrm{I}(2)$.

[Insert Table I and Table II here]

Having confirmed that none of the variables are integrated of order two (or higher), we proceed to apply the ARDL bounds test for cointegration. 
Table III presents the estimated values of the $F$ and $t$-BDM statistics of all the models at the $1 \%, 5 \%$ and $10 \%$ level of significance. For the models relating to the first hypothesis (that is, models 1 to 3 ), the test statistics exceed the upper critical bounds at the $10 \%$ level of significance in the total export and the oil export models. However, for the non-oil export model, the $t$-BDM and $F$ statistics fall below the lower critical bound value at the customary significance levels. We, therefore, conclude that there exists no long-run relationship between non-oil exports and the independent variables in the model.

In the models relating to the second hypothesis (that is, models 4 to 6 ), the estimates of the $F$ and $t$-BDM statistics show that there is a cointegrating relationship in the total export and the oil export models at the $1 \%$ significance level. For the non-oil export model, the two test statistics, again, fall below the lower critical bounds, hence we conclude that there is no long-run relationship between non-oil exports and the independent variables.

There are good explanations as to why there may be no cointegrating relationship between both aggregate and disaggregated FDI and non-oil exports in Nigeria. First, although FDI, especially FDI in the manufacturing sector, may be - at least in theory - expected to boost exports either through the exports of the MNE's affiliates or spillovers on the export capacity of domestic firms, the size of the investment and the motivation of the foreign investors matter in determining the impact of FDI on exports. If the level of FDI into the manufacturing sector is low, or the motivation for FDI is purely resource or market seeking or there are only few linkages between the domestic firms and manufacturing FDI, then it is possible that even manufacturing FDI may not have any long-run relationship with non-oil exports.

[Insert Table III here] 
The diagnostic tests presented in Table IV suggest that there is no serial correlation and heteroscedasticity, and that normality holds. Furthermore, the plots of the cumulative sum (CUSUM) and the cumulative sum of squares (CUSUMQ) presented in Figure 4 show that the there is no evidence of parameter instability.

[Insert Table IV and Figure 4 here]

\subsection{Aggregate FDI and exports}

Table IV presents the estimates of the long-run relationships and of the error correction models (ECMs) of our cointegrating models of aggregate FDI (we, therefore, do not estimate the non-cointegrating model of equation 3).

Looking first at Panel A of Table IV, in the first two models (1-2) pertaining to our first hypothesis (whether aggregate inward FDI has a positive effect on the volume of total exports and oil exports in Nigeria), we find that total FDI has a positive and highly statistically significant long-run relationship with both total exports as well as oil exports (not surprising given the prominent position of the oil sector in the Nigerian economy), with estimated coefficients of 1.150 and 1.209 , respectively. This is consistent with our a priori expectation that the inflow of FDI will increase the volume of exports in the host economy. This result is supported by the similar findings of Wang et al. (2007) for China, and Leichenko et al. (1997) for the U.S.

We also find that the estimated REER coefficient in both model 1 and model 2, is not statistically significant, suggesting that in the case of Nigeria the exchange rate does not play a significant role in export performance. Contrary to our a priori expectations, our results also suggest that there exists a long-run negative relationship between GDP and both total exports and oil exports, with highly statistically significant coefficients of -3.679 and -3.828 , 
respectively. Dodaro (1993) argues that this may be because an increase in GDP could boost aggregate domestic demand, which in turn may make firms focus more on the domestic market and less on international trade. This explanation bears relevance in the context of Nigeria, which is a very large and highly populated country. Also, in their analysis covering over 90 countries, Anwar and Sampath (2001) found that the relationship between GDP and exports, while positive in many countries, is negative for less developed economies.

The associated ECM results are presented in Panel B of Table IV. The short-run coefficients suggest that $D(L N F D I)$ has a short-run positive impact on total exports and oil exports while $D(L N R E E R)$ and $D(L N G D P)$ do not have a significant impact on total or oil exports in the short-run. The Error Correction Term (ECT) of -0.569 and -0.543 for the total export and oil export models, respectively, are statistically significant and suggest that it takes just short of two years for the adjustment from short-run disequilibrium to long-run equilibrium to be achieved.

\subsection{Sectoral FDI and exports}

Our bound tests for cointegration suggest that there exists a long-run relationship between sectoral FDI and total exports (model 4) and sectoral FDI and oil exports (model 5), but we do not find evidence of a cointegrating relationship between sectoral FDI and non-oil exports (model 6). Hence, we only estimate model 4 and model 5.

The short-run coefficients display mixed effects, significant only for $D(L N M F D I)$ and $D(L N S F D I)$ at $1 \%$, and $D(L N R E E R)$ at $10 \%$. Such effects are, by their very nature, shortlived. The ECT in both model 4 and model 5 is negative and statistically significant, as to be expected, with estimated values suggesting that about $90 \%$ and $63 \%$ of the adjustment from 
short-run disequilibrium to long-run equilibrium in the total export and oil export models, respectively, is completed within one year.

Our interest centres on the estimated long-run coefficients, which suggest that it is only primary sector FDI (LNPFDI) and manufacturing sector FDI (LNMFDI) that have a positive and statistically significant long-run impact on both total exports and oil exports. The effect is much more significant (at the $1 \%$ level) and more pronounced for $L N M F D I$, with an estimated coefficient of 1.486 and 1.526 in model 4 and 5, respectively. It is somewhat surprising that primary sector FDI has a positive long-run effect on total exports and oil exports only at the $10 \%$ significance level, with a coefficient of a smaller magnitude than manufacturing sector FDI given that the oil sector receives the greatest share of primary sector FDI, and it is well documented that FDI in primary sector in developing countries is usually export-oriented (see Hirschman, 1958; and Alfaro, 2003). However, the much higher and more significant elasticities for manufacturing sector FDI may be explained by the fact that manufacturing FDI helps in facilitating or constructing infrastructure that facilitates exports of all commodities as well as oil (Aitken et al., 1997). This is probably the case from our data, as our results suggest that, in the case of Nigeria, manufacturing FDI has a strong positive effect on total exports in general, and oil exports in particular (though not for non-oil exports, which did not bear a cointegrating relationship).

The coefficient of service sector FDI ( $L N S F D I)$, on the other hand, suggests that there is no statistically significant long-run relationship between service sector FDI and total exports or oil exports (though the short-run coefficients are significant with a negative and positive effect in model 4 and 5 , respectively). This result is not farfetched given that the service sector is still relatively underdeveloped in Nigeria. The estimated long-run REER coefficient (LNREER) is still negative but now statistically significant at the $10 \%$ level in the 
two models (4 and 5), while the estimated long-run GDP coefficient ( $L N G D P$ ) is statistically insignificant in the two models.

Taken together, our results suggest that while aggregate FDI has a positive long-run relationship with total exports in Nigeria, when disaggregated by export categories this relationship is significant only for oil exports. Moreover, when total FDI is disaggregated into sectors, the FDI-export nexus holds for primary and manufacturing FDI targeted at oil exports, not for non-oil exports. Services sector FDI does not bear any long-term relationship with Nigerian exports, whether oil or non-oil.

\section{Conclusion}

This study examines the direct impact of FDI on Nigeria's export performance by testing the effect of aggregate and sectoral FDI on total and disaggregated exports. By employing the ARDL cointegration technique, we find that aggregate FDI has a positive and statistically significant long-run relationship with total exports and oil exports. The evidence further suggests that there is no statistically significant impact of FDI on non-oil exports. A similar result is found when FDI is disaggregated according to sector. Both primary sector FDI and manufacturing sector FDI have a positive long-run relationship with total exports and oil exports. Service sector FDI, on the other hand, appears not to have a statistically significant long-run impact on exports at either aggregate or disaggregated level.

These findings lend themselves to straightforward policy recommendations. The Nigerian government ought to create incentives to attract the type of FDI that has a greater impact on exports, namely primary sector FDI and especially manufacturing sector FDI. That said, in order to reduce the dependence on the oil sector, it is important that Nigerian policymakers interested in export diversification, specifically incentivise the production and 
exports of non-oil export goods. Investment promotion priorities should be given to foreign firms who are more likely to increase local industrialisation. In addition, efforts should be made to improve the absorptive capacity of Nigeria and domestically-owned firms, so as to increase the probability that domestically-owned firms benefit from spillovers arising from the presence of these foreign firms.

Data availability permitting, investigation of the indirect spillover effect of FDI on domestic (Nigerian) firms' exports, would constitute a valuable extension of our analysis. Also, our study did not consider any possible nonlinearity in the relationship in question. It follows that investigation of a potentially significant nonlinear relationship between FDI and host country exports, at both aggregate and disaggregated level, provides a profitable avenue for future research. 


\section{References}

Aigheyisi, O.S. (2016), "Import penetration, FDI inflows and non-oil export performance in Nigeria (1981-2012): a cointegration and error correction analysis", Botswana Journal of Economics, Vol. 13 No. 1, pp. 40-67.

Aitken, B., Hanson, G.H. and Harrison, A.E. (1997), "Spillovers, foreign investment, and export behavior”, Journal of International Economics, Vol. 43 No. 1, pp. 103-132.

Alfaro, L. (2003), "Foreign direct investment and growth: does the sector matter", Harvard Business School, pp. 1-31.

Anwer, M.S. and Sampath, R.K. (2001), "Exports and economic growth”, Indian Economic Journal, Vol. 47 No. 3, pp. 79-88.

Bahmani-Oskooee, M. and Hajilee, M. (2013) "Exchange rate volatility and its impact on domestic investment", Research in Economics, Vol. 67, pp. 1-12.

Buckley, P.J. and Casson, M. (1976), The Future of the Multinational Enterprise. London: Macmillan.

De Vita, G. and Abbott, A. (2002), “Are saving and investment cointegrated? An ARDL bounds testing approach”, Economics Letters, Vol. 77, pp. 293-299.

Dodaro, S. (1993), "Exports and growth: a reconsideration of causality", Journal of Developing Areas, Vol. 27, pp. 227-44.

Enimola, S. (2011), "Foreign Direct Investment and Export Growth in Nigeria”, Journal of Economics and International Finance, Vol. 3 No.11, pp. 586-594. 
Fousekis, P., Katrakilidis, C. and Trachanas, E. (2016), "Vertical price transmission in the US beef sector: evidence from the nonlinear ARDL model", Economic Modelling, Vol. 52, pp. 499-506.

Franco, C. (2013), "Exports and FDI motivations: empirical evidence from U.S. foreign subsidiaries", International Business Review, Vol. 22 No. 1, pp. 47-62.

Gorg, H. and Greenaway, D. (2001), "Foreign direct investment and intra-industry spillovers: a review of the literature", Leverhulme Centre for Research on Globalisation and Economic Policy, No. 2001, 37.

Gu, W., Awokuse, T. and Yuan, Y. (2008), "The contribution of foreign direct investment to China's export performance: evidence from disaggregated sectors", IDEAS Working Paper Series from RePEc.

Hirschman, A. (1958), The Strategy of Economic Development. New Haven: Yale University Press.

Jensen, C. (2002), "Foreign direct investment, industrial restructuring and the upgrading of Polish exports", Applied Economics, Vol. 34 No. 2, pp. 207-217.

Koehler, A.B. and Murphree, E.S. (1988), "A comparison of the Akaike and Schwarz criteria for selecting model order", Journal of the Royal Statistical Society, Vol. 37 No. 2, pp. 187-195.

Kutan, A.M. and Vuksic, G. (2007), "Foreign direct investment and export performance: empirical evidence", Comparative Economic Studies, Vol. 49 No. 3, pp. 430-445. 
Lall, S. and Mohammad, S. (1983), "Foreign ownership and export performance in the large corporate sector of India”, The Journal of Development Studies, Vol. 20 No. 1, pp. 5667.

Leichenko, R.M. and Erickson, R.A. (1997), "Foreign direct investment and state export performance”, Journal of Regional Science, Vol. 37 No. 2, pp. 307-329.

Li, C., Murshed, S.M. and Tanna, S. (2017), “The impact of civil war on foreign direct investment flows to developing countries", The Journal of International Trade \& Economic Development, Vol. 26 No. 2, pp. 488-507.

Liu, X. and Shu, C. (2003), "Determinants of export performance: evidence from Chinese industries", Economics of Planning, Vol. 36 No. 1, pp. 45-67.

Mohammed S. and Ekundayo B.I. (2014), "Foreign direct investment-trade nexus in Nigeria: do structural breaks matter?” CBN Economic and Financial Review, Vol. 52 No. 1, pp. $1-27$.

Mundell, R.A. (1957), "International trade and factor mobility”, The American Economic Review, Vol. 47 No. 3, pp. 321-335.

Ng, S. and Perron, P. (2001), "Lag length selection and the construction of unit root tests with good size and power". Econometrica, Vol. 69 No. 6, pp. 1519-1554.

Olayiwola, K. and Okodua, H. (2013), "Foreign direct investment, non-oil exports, and economic growth in Nigeria: a causality analysis", Asian Economic and Financial Review, Vol. 3 No. 11, pp. 1479-1496. 
Onyekwena, C., Ademuyiwa, I. and Uneze, E. (2015), “Trade and foreign direct investment nexus in West Africa: does export category matter?", CSEA Working Paper WPS/15/01.

Pesaran, M.H. and Shin, Y. (1999), “An Autoregressive Distributed Lag Modelling Approach to Cointegration Analysis", in Econometrics and Economic Theory in the 20th Century: The Ragnar Frisch Centennial Symposium (ed.) by Strom, S. Cambridge: Cambridge University Press.

Pesaran, M.H., Shin, Y., and Smith, R.J. (2001), "Bounds testing approaches to the analysis of level relationships", Journal of Applied Econometrics, Vol. 16 No. 3, pp. 289-326.

Sharma, K. (2003), “Factors determining India's export performance”, Journal of Asian Economics, Vol. 14 No. 3, pp. 435-446.

Sun, H. (2001), "Foreign direct investment and regional export performance in China", Journal of Regional Science, Vol. 41 No. 2, pp. 317-336.

UNCTAD. (2001), “The world of investment promotion at a glance: a survey of investment promotion practices”, United Nations Advisory Study 17, UNCTAD/ITE/IPC/3.

UNCTAD. (2007), “World Investment Report”, United Nations: Geneva.

Vuksic, G. (2005), "Impact of foreign direct investment on Croatian manufacturing exports", Financial Theory and Practice, Vol. 29 No. 2, pp. 131-158.

Wang, C., Buckley, P.J., Clegg, J. and Kafouros, M. (2007), “The impact of inward foreign direct investment on the nature and intensity of Chinese manufacturing exports", Transnational Corporations, Vol. 16 No. 2, pp. 123-141. 
Xuan, N.T. and Xing, Y. (2008), "Foreign direct investment and exports: the experiences of Vietnam”, Economics of Transition, Vol. 16 No. 2, pp. 183-197.

Zhang, K.H. (2005), “How does FDI affect a host country's export performance? The case of China", Paper presented in International Conference of WTO, China, and the Asian Economies, III. In Xi'an, China, June 25-26.

Zhang, K.H. and Song, S. (2002), "Promoting exports: the role of inward FDI in China", China Economic Review, Vol. 11 No. 4, pp. 385-396. 


\section{Figure 1}

Inward FDI flows in Nigeria by sector from 1980 to 2009.

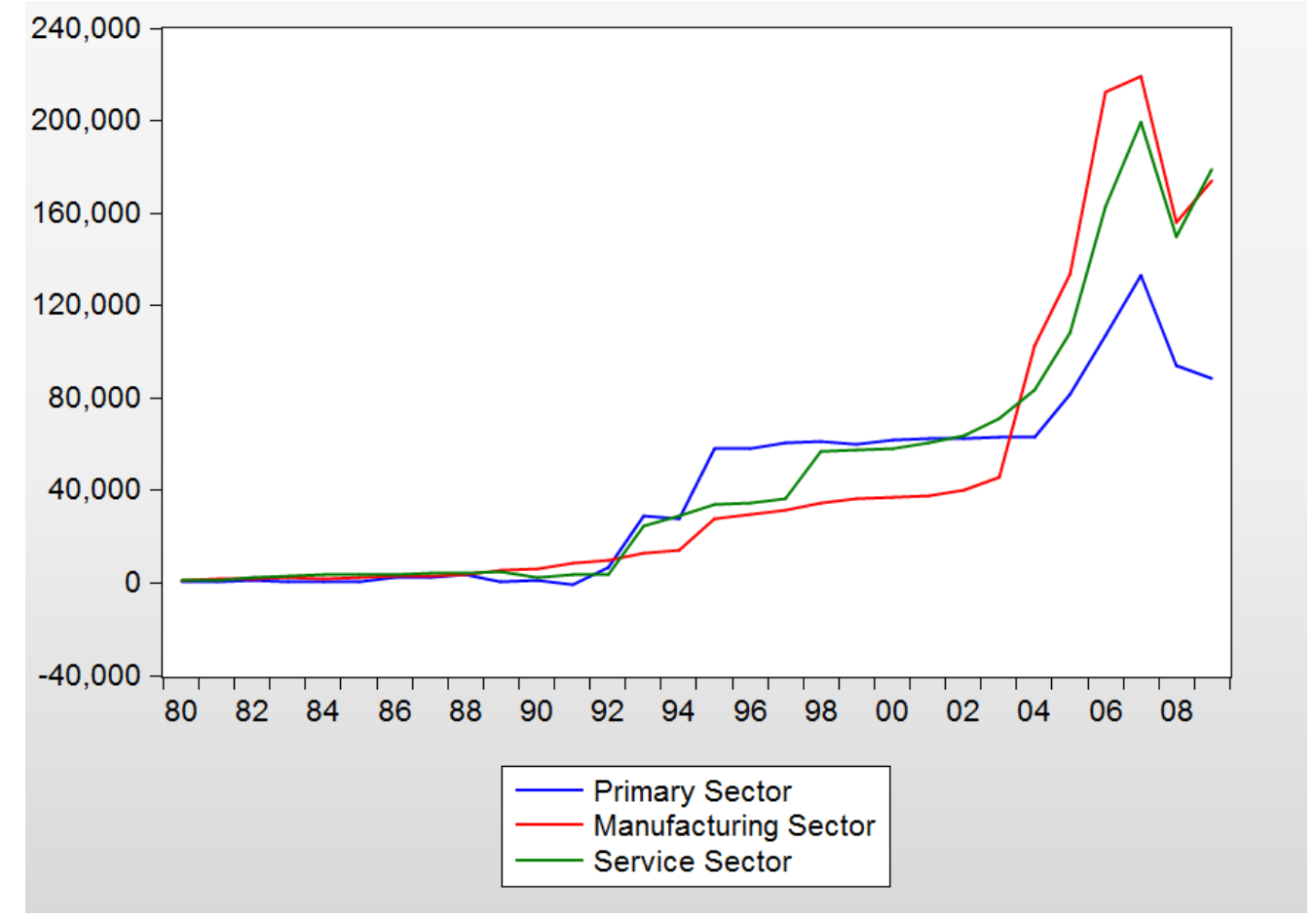

Source: CBN Statistical Bulletin 2009.

Figure 2

Top 10 destinations of FDI in Africa (average 1980 to 2015)

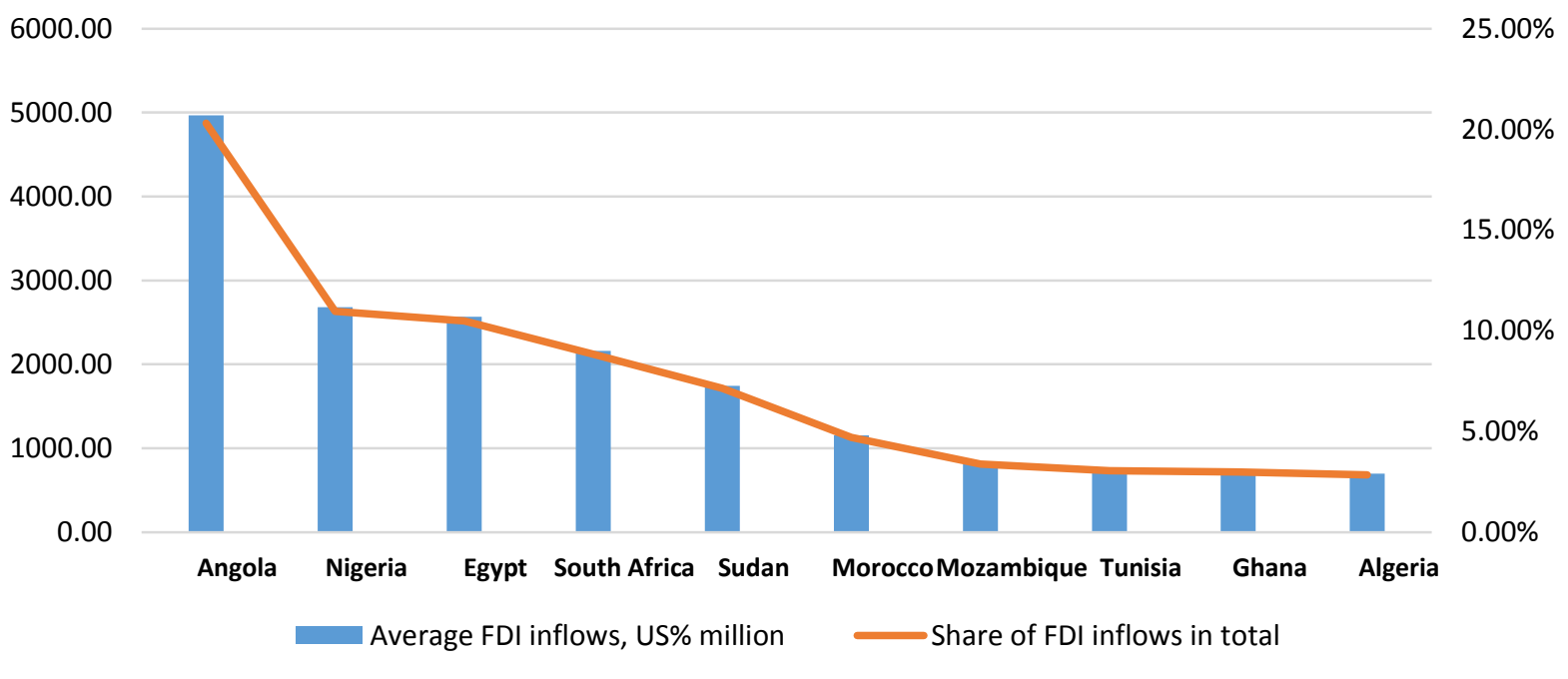

Source: Calculations based on data from UNCTAD. 
Figure 3

Summary of export in Nigeria: Total, Oil and Non-Oil (N' Billion)

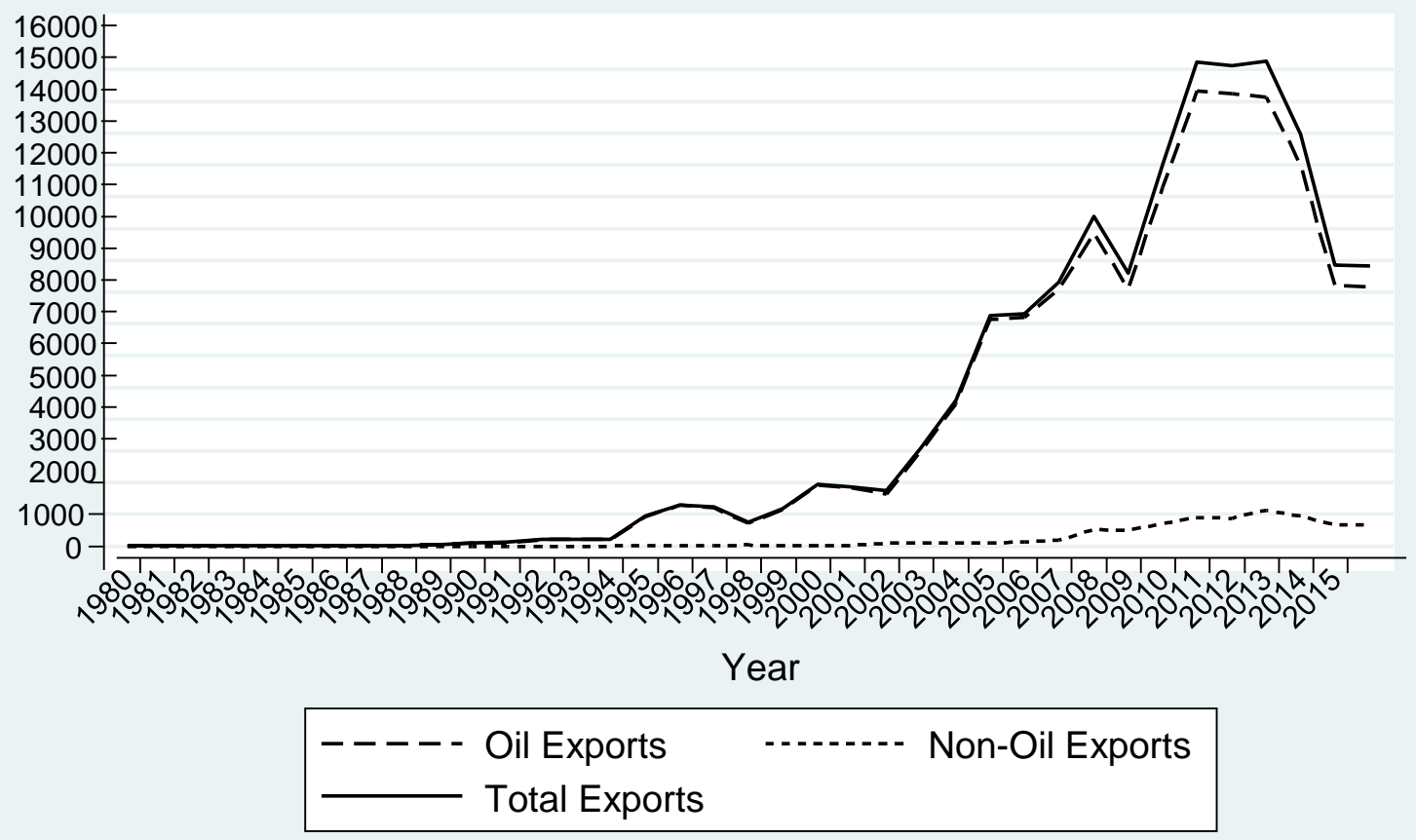

Source:CBN Statistical Bulletin 2016. 
Figure 4

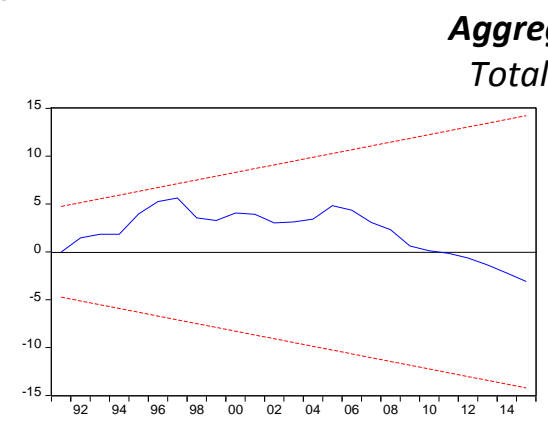

CUSUM ..... $5 \%$ significance

\section{Oil export}
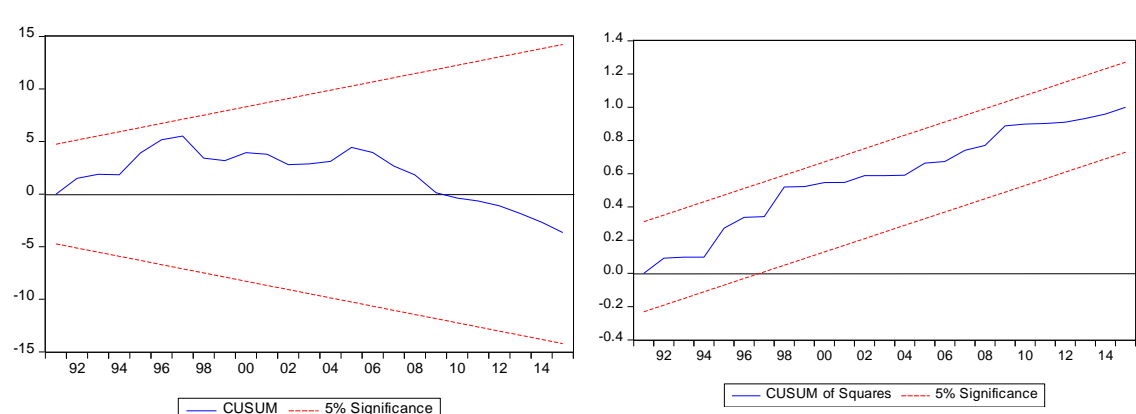

Non-oil export

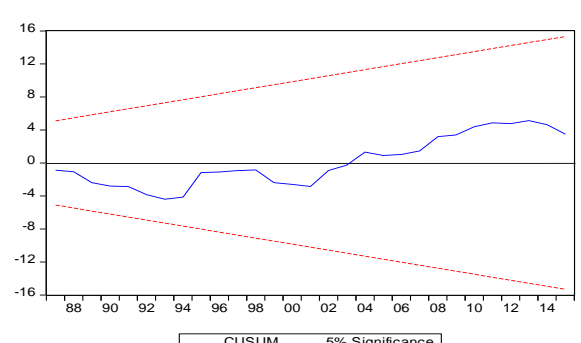

- CUSUM -... $5 \%$ Significance

\section{CUSUM and CUSUMSQ for the ARDL Models}

Sectoral FDI

Total export

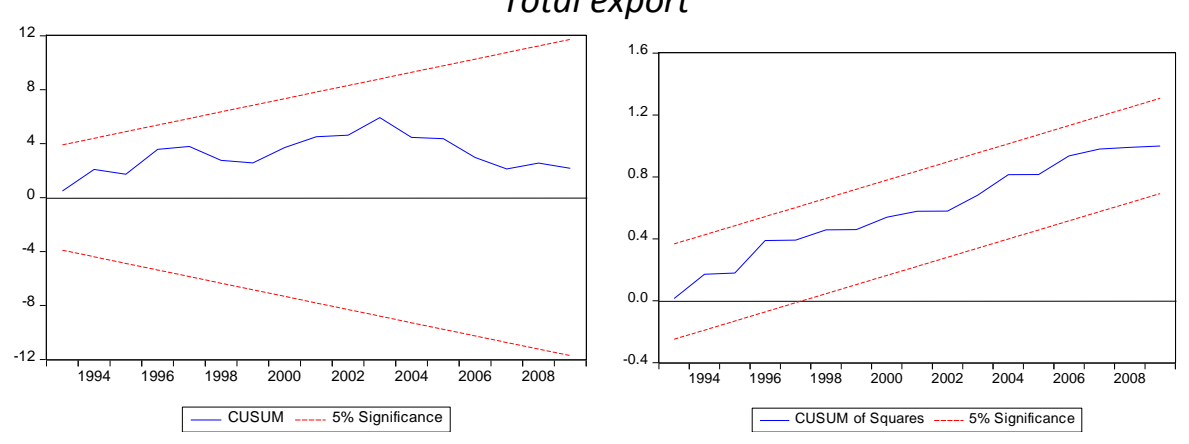

Oil export

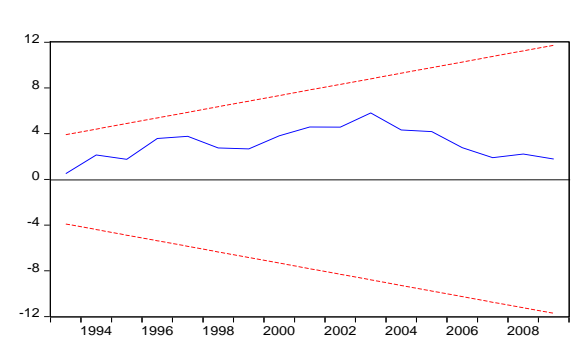

- cusum -..-5\% Significance

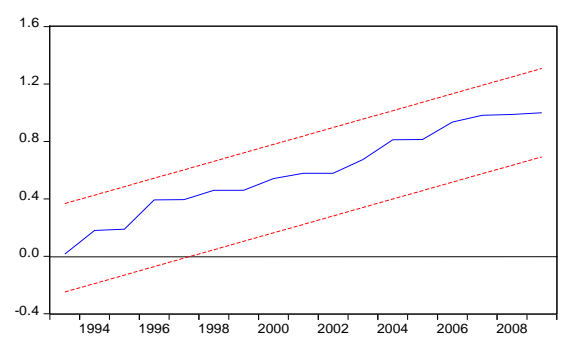

- CUSUM of Squares -... $5 \%$ Significance

Non-oil export
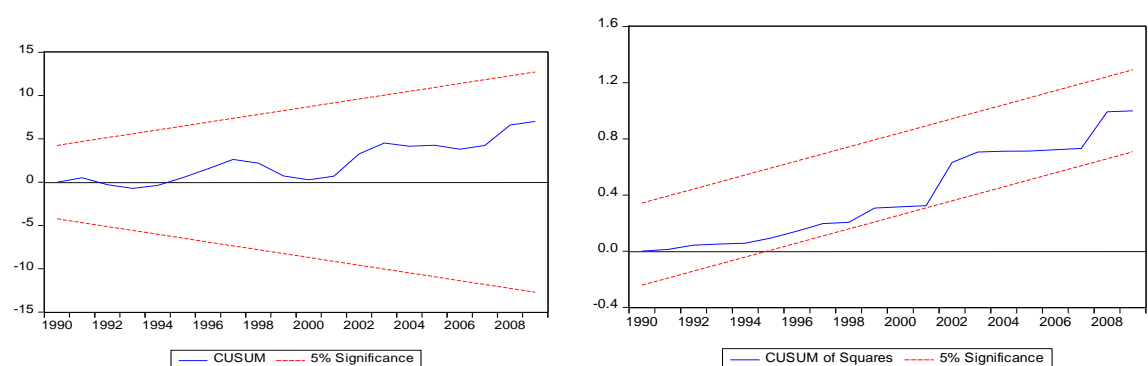

- Cusum of Squares -...- $5 \%$ Significance 
Table I.

$\mathrm{Ng}$ and Perron (2001) and ADF unit root tests.

\begin{tabular}{|c|c|c|c|c|c|c|c|c|c|c|c|c|}
\hline \multicolumn{7}{|c|}{ constant only } & \multicolumn{6}{|c|}{ constant and time trend } \\
\hline Variables & $M Z_{a}^{G L S}$ & $M Z_{t}^{G L S}$ & $M S B^{G L S}$ & $M P_{T}^{G L S}$ & $\mathrm{ADF}$ & $k$ & $M Z_{a}^{G L S}$ & $M Z_{t}^{G L S}$ & $M S B^{G L S}$ & $M P_{T}^{G L S}$ & ADF & $k$ \\
\hline LNFDI & -0.971 & -0.597 & 0.615 & 20.348 & -0.814 & 0 & -13.455 & -2.526 & 0.187 & 7.1473 & $-7.241^{* * *}$ & 1 \\
\hline LNOEXP & 0.438 & 0.458 & 1.046 & 66.978 & -0.942 & 0 & -5.144 & -1.357 & 0.263 & 16.687 & -1.233 & 0 \\
\hline LNNEXP & 0.677 & 0.628 & 0.927 & 56.876 & -0.542 & 0 & -11.136 & -2.260 & 0.203 & 8.668 & $-3.426^{*}$ & 0 \\
\hline LNTEXP & 0.500 & 0.531 & 1.061 & 69.657 & -0.898 & 0 & -5.329 & -1.401 & 0.262 & 16.310 & -1.330 & 0 \\
\hline LNREER & -3.977 & -1.396 & 0.351 & 6.171 & -1.930 & 0 & -5.809 & -1.653 & 0.284 & 15.592 & -1.771 & 0 \\
\hline$L N G D P$ & 1.096 & 0.764 & 0.697 & 37.897 & 1.676 & 0 & -1.365 & -0.689 & 0.504 & 50.729 & -0.205 & 0 \\
\hline$\triangle L N F D I$ & $-13.475^{\star *}$ & $-2.583^{\star * *}$ & 0.191 & $1.864^{\star *}$ & $-10.791^{* * *}$ & 1 & -11.699 & -2.390 & 0.204 & 7.936 & $-10.610^{* * *}$ & 1 \\
\hline$\triangle L N O E X P$ & $-16.460^{* * *}$ & $-2.839^{\star \star \star}$ & $0.172^{\star \star *}$ & $1.598^{* * *}$ & $-5.789^{* * *}$ & 1 & $-16.598^{*}$ & $-2.826^{*}$ & $0.170^{*}$ & $5.808^{*}$ & $-4.503^{\star * *}$ & 1 \\
\hline$\triangle L N N E X P$ & $-6.277^{*}$ & $-1.757^{*}$ & 0.279 & $3.948^{*}$ & $-6.468^{* * *}$ & 1 & $-16.240^{*}$ & $-2.786^{*}$ & $0.171^{*}$ & $5.980^{*}$ & $-6.355^{\star \star *}$ & 1 \\
\hline$\triangle L N T E X P$ & $-16.432^{* \star *}$ & $-2.845^{\star \star \star}$ & $0.173^{\star * *}$ & $1.568^{\star \star *}$ & $-5.849^{* * *}$ & 1 & $-16.585^{\star}$ & $-2.834^{*}$ & $0.170^{*}$ & $5.760^{*}$ & $-4.547^{* * *}$ & 1 \\
\hline$\triangle L N R E E R$ & $-15.825^{\star * *}$ & $-2.812^{\star \star \star}$ & $0.177^{* *}$ & $1.549^{* * *}$ & $-4.403^{\star \star \star}$ & 1 & $-15.929^{*}$ & $-2.822^{*}$ & $0.177^{*}$ & $5.721^{*}$ & $-4.416^{\star * \star}$ & 1 \\
\hline$\triangle L N G D P$ & $-6.210^{*}$ & $-1.740^{*}$ & 0.280 & $4.014^{*}$ & $-4.824^{\star \star \star}$ & 1 & $-15.651^{*}$ & $-2.743^{*}$ & $0.175^{*}$ & $6.135^{*}$ & $-5.330^{\star \star *}$ & 1 \\
\hline \multicolumn{13}{|c|}{ Critical values } \\
\hline $1 \%$ & -13.80 & -2.58 & 0.174 & 1.78 & & & -23.80 & -3.42 & 0.143 & 4.03 & & \\
\hline $5 \%$ & -8.10 & -1.98 & 0.233 & 3.17 & & & -17.30 & -2.91 & 0.168 & 5.48 & & \\
\hline $10 \%$ & -5.70 & -1.62 & 0.275 & 4.45 & & & -14.20 & -2.62 & 0.185 & 6.67 & & \\
\hline
\end{tabular}

Notes: $\Delta$ denotes the first difference operator while $k$ denotes the order of integration of the series. The critical values are from $\mathrm{Ng}$ and Perron $(2001) . * * * * *$ and $*$ denote the rejection of the null of a unit root at the 1\%, 5\% and 10\% significance level, respectively. Ng and Perron (2001) combine GLS detrending with SD to design a new test. The proposed test consists of a suite of four tests, namely $M Z_{a}^{G L S}, M Z_{t}^{G L S}, M S B^{G L S}$ and $M P_{T}^{G L S}$ to correct for size distortions when residuals are negatively correlated. For the ADF tests, a maximum lag length of eight lags was used. 
Table II.

Ng-Perron (2001) and ADF unit root tests.

\begin{tabular}{|c|c|c|c|c|c|c|c|c|c|c|c|c|}
\hline \multicolumn{6}{|c|}{ constant only } & \multicolumn{7}{|c|}{ constant and time trend } \\
\hline Variables & $M Z_{a}^{G L S}$ & $M Z_{t}^{G L S}$ & $M S B^{G L S}$ & $M P_{T}^{G L S}$ & $\mathrm{ADF}$ & $k$ & $M Z_{a}^{G L S}$ & $M Z_{t}^{G L S}$ & $M S B^{G L S}$ & $M P_{T}^{G L S}$ & $\mathrm{ADF}$ & $k$ \\
\hline LNOEXP & 0.702 & 0.666 & 0.948 & 59.365 & 59.365 & 0 & -8.540 & -1.968 & 0.230 & 10.976 & -.2 .527 & 0 \\
\hline LNNEXP & 1.207 & 0.956 & 0.791 & 47.698 & 47.698 & 0 & -11.592 & -2.404 & 0.207 & 7.875 & -4.074 & 0 \\
\hline LNTEXP & 0.737 & 0.705 & 0.957 & 60.825 & 60.825 & 0 & -8.625 & -1.983 & 0.229 & 10.867 & -2.556 & 0 \\
\hline LNREEF & -3.381 & -1.251 & 0.370 & 7.2105 & 7.2105 & 0 & -5.369 & -1.615 & 0.300 & 16.887 & -1.755 & 0 \\
\hline$L N G D P$ & 0.893 & 0.440 & 0.492 & 21.593 & 21.593 & 0 & -1.242 & -0.518 & 0.417 & 39.704 & -1.650 & 0 \\
\hline LNPFDI & -1.037 & -0.542 & 0.523 & 16.343 & 16.343 & 0 & -8.019 & -1.934 & 0.241 & 11.537 & -2.150 & 0 \\
\hline LNMFDI & 0.553 & 0.383 & 0.692 & 33.867 & 33.867 & 0 & $-327.563^{\star * *}$ & $-12.792^{\star * \star}$ & $0.0390^{* * *}$ & $0.290^{* * *}$ & $-3.754^{* *}$ & 1 \\
\hline LNSFDI & 0.969 & 0.689 & 0.711 & 38.180 & 38.183 & 0 & -6.1605 & -1.753 & 0.284 & 14.790 & -1.909 & 0 \\
\hline$\triangle L N O E X P$ & $-13.212^{\star *}$ & $-2.556^{\star *}$ & $0.193^{\star *}$ & $1.906^{\star *}$ & $1.906^{\star *}$ & 1 & -12.817 & -2.489 & 0.194 & 7.334 & $-4.574^{\star \star \star}$ & 1 \\
\hline$\triangle L N N E X P$ & $-13.120^{* *}$ & $-2.559^{* *}$ & $0.195^{\star *}$ & $1.874^{\star *}$ & $1.874^{\star \star}$ & 1 & -12.353 & -2.457 & 0.198 & 7.524 & $-6.494^{\star * *}$ & 1 \\
\hline$\triangle L N T E X P$ & $-13.192^{* *}$ & $-2.555^{\star *}$ & $0.193^{\star *}$ & $1.907^{\star *}$ & $1.907^{\star *}$ & 1 & -12.789 & -2.486 & 0.194 & 7.353 & $-4.579^{\star * \star}$ & 1 \\
\hline$\triangle L N R E E R$ & $-12.689^{* *}$ & $-2.518^{* *}$ & $0.198^{* *}$ & $1.933^{* *}$ & $1.933^{\star *}$ & 1 & -12.727 & -2.521 & 0.198 & 7.168 & $-3.880^{* *}$ & 1 \\
\hline$\triangle L N G D P$ & $-9.667^{* *}$ & $-2.158^{* *}$ & $0.223^{* *}$ & $2.686^{* *}$ & $2.686^{\star *}$ & 1 & -12.840 & -2.510 & 0.195 & 7.222 & $-5.163^{* * *}$ & 1 \\
\hline$\triangle L N P F D I$ & $-13.037^{* *}$ & $-2.544^{\star \star}$ & $0.195^{\star *}$ & $1.911^{* *}$ & $1.911^{* *}$ & 1 & -12.998 & -2.548 & 0.196 & 7.0136 & $-5.955^{\star * *}$ & 1 \\
\hline$\triangle L N M F D I$ & $-13.359^{* *}$ & $-2.583^{* * *}$ & $0.193^{* *}$ & $1.839^{* *}$ & $1.839^{\star *}$ & 1 & -13.366 & -2.582 & 0.193 & 6.831 & $-4.462^{\star * *}$ & 1 \\
\hline$\triangle L N S F D I$ & $-13.037^{* *}$ & $-2.541^{\star *}$ & $0.194^{\star *}$ & $1.922^{\star *}$ & $1.922^{\star *}$ & 1 & -12.900 & -2.539 & 0.196 & 7.064 & $-5.769^{\star * *}$ & 1 \\
\hline \multicolumn{13}{|c|}{ Critical values } \\
\hline $1 \%$ & -13.80 & -2.58 & 0.174 & 1.78 & & & -23.80 & -3.42 & 0.143 & 4.03 & & \\
\hline $5 \%$ & -8.10 & -1.98 & 0.233 & 3.17 & & & -17.30 & -2.91 & 0.168 & 5.48 & & \\
\hline $10 \%$ & -5.70 & -1.62 & 0.275 & 4.45 & & & -14.20 & -2.62 & 0.185 & 6.67 & & \\
\hline
\end{tabular}

Notes: $\Delta$ denotes the first difference operator while $k$ denotes the order of integration of the series. The critical values are from $\mathrm{Ng}$ and Perron $(2001)$. ***,** and $*$ denote the rejection of the null hypothesis of a unit root at the $1 \%, 5 \%$ and $10 \%$ significance level, respectively. $\mathrm{Ng}$ and Perron (2001) combine GLS detrending with SD to design a new test. The proposed test consists of a suite of four tests, namely $M Z_{a}^{G L S}, M Z_{t}^{G L S}, M S B^{G L S}$ and $M P_{T}^{G L S}$ to correct for size distortions when residuals are negatively correlated. For the ADF tests, a maximum lag length of eight lags was used. 
Table III.

Bounds testing for cointegration (equations 1-6).

\begin{tabular}{|c|c|c|c|c|c|c|c|c|c|c|c|c|}
\hline \multicolumn{7}{|c|}{ Aggregate FDI } & \multicolumn{6}{|c|}{ Sectoral FDI } \\
\hline & \multicolumn{2}{|c|}{ Total Export (1) } & \multicolumn{2}{|c|}{ Oil Export (2) } & \multicolumn{2}{|c|}{ Non-Oil Export(3) } & \multicolumn{2}{|c|}{ Total Export (4) } & \multicolumn{2}{|c|}{ Oil Export (5) } & \multicolumn{2}{|c|}{ Non-Oil Export(6) } \\
\hline F-statistic & \multicolumn{2}{|c|}{4.209} & \multicolumn{2}{|c|}{4.060} & \multicolumn{2}{|c|}{1.110} & \multicolumn{2}{|c|}{7.081} & \multicolumn{2}{|c|}{7.148} & \multicolumn{2}{|c|}{1.122} \\
\hline & \multicolumn{6}{|c|}{ Critical Value Bounds } & \multicolumn{6}{|c|}{ Critical Value Bounds } \\
\hline Significance & $\begin{array}{c}\mathrm{I}(0) \\
\text { Bound }\end{array}$ & $\begin{array}{c}\text { I(1) } \\
\text { Bound }\end{array}$ & $\begin{array}{c}\mathrm{I}(0) \\
\text { Bound }\end{array}$ & $\begin{array}{c}\mathrm{I}(1) \\
\text { Bound }\end{array}$ & $\begin{array}{c}\mathrm{I}(0) \\
\text { Bound }\end{array}$ & $\begin{array}{c}\mathrm{I}(1) \\
\text { Bound }\end{array}$ & $\begin{array}{c}\mathrm{I}(0) \\
\text { Bound }\end{array}$ & $\begin{array}{c}\mathrm{I}(1) \\
\text { Bound }\end{array}$ & $\begin{array}{c}\mathrm{I}(0) \\
\text { Bound }\end{array}$ & $\begin{array}{c}\mathrm{I}(1) \\
\text { Bound }\end{array}$ & $\begin{array}{c}\mathrm{I}(0) \\
\text { Bound }\end{array}$ & $\begin{array}{c}\mathrm{I}(1) \\
\text { Bound }\end{array}$ \\
\hline $10 \%$ & 2.97 & 3.74 & 2.97 & 3.74 & 2.97 & 3.74 & 2.58 & 3.86 & 2.58 & 3.86 & 2.58 & 3.86 \\
\hline $5 \%$ & 3.38 & 4.23 & 3.38 & 4.23 & 3.38 & 4.23 & 3.12 & 4.61 & 3.12 & 4.61 & 3.12 & 4.61 \\
\hline $2.5 \%$ & 3.8 & 4.68 & 3.8 & 4.68 & 3.8 & 4.68 & 4.54 & 6.37 & 4.54 & 6.37 & 4.54 & 6.37 \\
\hline $1 \%$ & 4.3 & 5.23 & 4.3 & 5.23 & 4.3 & 5.23 & 2.58 & 3.86 & 2.58 & 3.86 & 2.58 & 3.86 \\
\hline \multirow[t]{2}{*}{$\mathrm{t}-\mathrm{BDM}$} & \multicolumn{2}{|c|}{-3.911} & \multicolumn{2}{|c|}{-3.924} & \multicolumn{2}{|c|}{ "-1.090 } & \multicolumn{2}{|c|}{-5.926} & \multicolumn{2}{|c|}{-5.914 } & \multicolumn{2}{|c|}{-2.477} \\
\hline & \multicolumn{6}{|c|}{ Critical Value Bounds } & \multicolumn{6}{|c|}{ Critical Value Bounds } \\
\hline Significance & $\begin{array}{c}\mathrm{I}(0) \\
\text { Bound }\end{array}$ & $\begin{array}{c}\text { I(1) } \\
\text { Bound }\end{array}$ & $\begin{array}{c}\mathrm{I}(0) \\
\text { Bound }\end{array}$ & $\begin{array}{c}\text { I(1) } \\
\text { Bound }\end{array}$ & $\begin{array}{c}\mathrm{I}(0) \\
\text { Bound }\end{array}$ & $\begin{array}{c}\mathrm{I}(1) \\
\text { Bound }\end{array}$ & $\begin{array}{c}\mathrm{I}(0) \\
\text { Bound }\end{array}$ & $\begin{array}{c}\mathrm{I}(1) \\
\text { Bound }\end{array}$ & $\begin{array}{c}\mathrm{I}(0) \\
\text { Bound }\end{array}$ & $\begin{array}{c}\mathrm{I}(1) \\
\text { Bound }\end{array}$ & $\begin{array}{c}\mathrm{I}(0) \\
\text { Bound }\end{array}$ & $\begin{array}{c}\mathrm{I}(1) \\
\text { Bound }\end{array}$ \\
\hline $10 \%$ & -3.13 & -3.84 & -3.13 & -3.84 & -3.13 & -3.84 & -2.57 & -3.86 & -2.57 & -3.86 & -2.57 & -3.86 \\
\hline $5 \%$ & -3.41 & -4.16 & -3.41 & -4.16 & -3.41 & -4.16 & -2.86 & -4.19 & -2.86 & -4.19 & -2.86 & -4.19 \\
\hline $2.5 \%$ & -3.65 & -4.42 & -3.65 & -4.42 & -3.65 & -4.42 & -3.13 & -4.46 & -3.13 & -4.46 & -3.13 & -4.46 \\
\hline $1 \%$ & -3.96 & -4.73 & -3.96 & -4.73 & -3.96 & -4.73 & -3.43 & -4.79 & -3.43 & -4.79 & -3.43 & -4.79 \\
\hline
\end{tabular}


Table IV.

Error correction and cointegration models.

\begin{tabular}{|c|c|c|c|c|c|}
\hline \multicolumn{6}{|c|}{ Panel A: Long-run coefficients } \\
\hline \multicolumn{3}{|c|}{ Aggregate FDI } & \multicolumn{3}{|c|}{ Sectoral FDI } \\
\hline Variable & Total Export (1) & Oil Export (2) & Variable & Total Export (4) & Oil Export (5) \\
\hline LNREER & $\begin{array}{l}-0.098 \\
(0.681)\end{array}$ & $\begin{array}{l}-0.117 \\
(0.652)\end{array}$ & LNREER & $\begin{array}{c}-0.303 * \\
(0.060)\end{array}$ & $\begin{array}{l}-0.292 * \\
(0.073)\end{array}$ \\
\hline LNGDP & $\begin{array}{l}-3.679 * * * \\
(0.000)\end{array}$ & $\begin{array}{l}-3.828 * * * \\
(0.000)\end{array}$ & LNGDP & $\begin{array}{l}-0.5693 \\
(0.544)\end{array}$ & $\begin{array}{l}-0.648 \\
(0.497)\end{array}$ \\
\hline LNFDI & $\begin{array}{l}1.150^{* * * *} \\
(0.001)\end{array}$ & $\begin{array}{l}1.209 * * * \\
(0.002)\end{array}$ & LNPFDI & $\begin{array}{l}0.268 * \\
(0.070)\end{array}$ & $\begin{array}{l}0.258^{*} \\
(0.085)\end{array}$ \\
\hline \multirow[t]{3}{*}{$\mathrm{C}$} & $\begin{array}{l}41.637^{* * *} \\
(0.000)\end{array}$ & $\begin{array}{l}41.211 * * * \\
(0.000)\end{array}$ & LNMFDI & $\begin{array}{l}1.486^{* * *} \\
(0.000)\end{array}$ & $\begin{array}{l}1.526 * * * \\
(0.000)\end{array}$ \\
\hline & & & LNSFDI & $\begin{array}{l}-0.300 \\
(0.242)\end{array}$ & $\begin{array}{l}-0.306 \\
(0.240)\end{array}$ \\
\hline & & & $\mathrm{C}$ & $\begin{array}{l}7.785 \\
(0.711)\end{array}$ & $\begin{array}{l}9.493 \\
(0.657)\end{array}$ \\
\hline \multicolumn{6}{|c|}{ Panel B: Short-run coefficients } \\
\hline \multicolumn{3}{|c|}{ Aggregate FDI } & \multicolumn{3}{|c|}{ Sectoral FDI } \\
\hline Variable & Total Export (1) & Oil Export (2) & Variable & Total Export (4) & Oil Export (5) \\
\hline D(LNREER) & $\begin{array}{l}-0.129 \\
(0.431)\end{array}$ & $\begin{array}{l}-0.144 \\
(0.392)\end{array}$ & D(LNREER) & $\begin{array}{l}-0.226^{*} \\
(0.074)\end{array}$ & $\begin{array}{l}-0.217^{*} \\
(0.091)\end{array}$ \\
\hline D(LNGDP) & $\begin{array}{l}0.008 \\
(0.992)\end{array}$ & $\begin{array}{l}0.073 \\
(0.938)\end{array}$ & D(LNGDP) & $\begin{array}{l}-0.503 \\
(0.463)\end{array}$ & $\begin{array}{l}-0.521 \\
(0.454)\end{array}$ \\
\hline $\mathrm{D}(\mathrm{LNFDI})$ & $\begin{array}{l}0.251^{* *} \\
(0.048)\end{array}$ & $\begin{array}{l}0.254^{*} \\
(0.051)\end{array}$ & D(LNPFDI) & $\begin{array}{l}-0.012 \\
(0.851)\end{array}$ & $\begin{array}{l}-0.011 \\
(0.864)\end{array}$ \\
\hline ECT(-1) & $\begin{array}{l}-0.569 * * * \\
(0.000)\end{array}$ & $\begin{array}{l}-0.543 * * * \\
(0.000)\end{array}$ & D(LNMFDI) & $\begin{array}{l}1.142^{* * * *} \\
(0.000)\end{array}$ & $\begin{array}{l}-0.230^{* * *} \\
(0.005)\end{array}$ \\
\hline & & & D(LNSFDI) & $\begin{array}{l}-0.624 * * * \\
(0.003)\end{array}$ & $\begin{array}{l}1.164 * * * \\
(0.000)\end{array}$ \\
\hline
\end{tabular}


ECT(-1) -0.903*** $-0.633 * *$

$(0.000) \quad(0.004)$

Diagnostics

HETER

$0.299(0.589)$

$1.377(0.254)$

$1.162(0.559)$

SC

$\begin{array}{ll}1.261(0.306) & \text { HETER } \\ 0.953(0.620) & \text { NORM }\end{array}$

$2.179(0.147)$

NORM

$1.017(0.464)$

$2.1834(0.147)$

$0.953(0.620)$

$0.352(0.838)$

$1.033(0.454)$

Notes: Probabilities values are presented in parenthesis. ***, ** and * denote the rejection of the null hypothesis of a unit root at the $1 \%, 5 \%$ and $10 \%$ significance level,

respectively. The optimal lag structure is selected by AIC, starting with max 2 lags. SC denotes the Breusch and Godfrey serial correlation test, HETER denotes the

Breusch and Pagan heteroscedasticity test, and NORM denotes the Jarque-Bera test for normality. 